\title{
Humor as a Survival Technique during Communism in Romania ${ }^{1}$
}

\author{
MIRUNA IACOB
}

\begin{abstract}
Humour is generally considered a universal feature, but it is also a context-related notion and it may involve the specificity of a certain culture. The present paper attempts to explore the ethics of humor and its subversive nature perceived as a survival technique during the communist regime in Romania, with an emphasis on Ioan Groșan's short story, The Island. Being in a constant battle with censorship, humour often proves to be a form of dissidence. Critical laughter functions as a corrective, undermining political principles and denouncing their inflexibility aimed at achieving a progressive social degradation. Therefore, a theoretical re-evaluation of the relationship between context and humor will reveal that the latter concept - with its forms and variations - becomes the escape from the gangrenous tissues of totalitarian societies.
\end{abstract}

Keywords: humour; subversion; totalitarianism; literature; context

\section{Postmodernism, Communism and Humour}

Although many philosophers and scholars have tried to define the concept of "humour" by taking into consideration all the possible means that would allow them to come closer to the essence of this notion, no clear definition of humour has ever been provided so far. Instead, we have a series of studies focusing on how humour works and how it can shape and influence the relationship among individuals in a certain community. There are three major theories to take into account in almost any discussion about humour, namely the Superiority Theory, the Relief Theory and the Incongruity Theory. The present paper will center on the ethics of humour and its subversive nature within a totalitarian regime in Romania, and on how critical laughter and undermining humour in literature can prove to be subtle but illustrative ways of criticizing the socio-political

1 This work was supported by a grant of the Romanian National Authority for Scientific Research and Innovation, CNCS-UEFISCDI, project number PN-II-RUTE-2014-4-0240. 
system. I shall try to stress the importance of the relationship between humour and context as well as the major differences between humour in communist countries with an intrinsic high power-distance, and humour derived from free speech in the Western part of Europe.

I will further on focus on three major axes, namely communism - humour postmodernism and their relation to literature. What these three key-concepts have in common is the idea of incongruity, discrepancy, disagreement, disproof, the unusual cohabitation of the opposites within the same space. Of the previously mentioned theories of humour, I shall choose the one which fits best my attempt to reveal the main traits and specificity of the Romanian humour, namely the Incongruity theory. Since my intention is to discuss the notion of incongruity in relation to postmodernism and communism in Romania, I believe the most appropriate way to begin is by turning to Schultz's definition of this concept, namely that incongruity is a conflict between what is expected and what actually occurs. (Schultz 1976: 12-13)

As far as the communist regime is concerned, the systemic incongruity of the system stems from the erroneous mechanisms which led to the predictable economic collapse, caused by the lack of free market and the materialization of a modus vivendi immersed in a continuous mystification of reality and values (Bremmer 2010: 20). In this political context, ethics as value is a notion left behind in order to make room for behavioral vices and consented corruption. The reunion of opposites envisioned by Hegel and passed through Marx's revolutionary filter ended up being a tangible nightmarish reality. The distortion of reality reached such a high level, that it became ideological fiction itself. Thus, in a world governed by political singularity, writers found refuge in their own fiction, in parallel universes, in alternatives to the adversity of a totalitarian regime which does not pay any attention to the private sphere of the individual. This hostile situation also brought about an identity crisis caused by a forced reinterpretation of the public-private relationship, by which the private sphere is affiliated to the public sphere. The one-dimensional New Man is born by the segregation of these compartments, the resection of the spirit being the sacrifice, the offering for the perfect society. In this sense, Todorov said that "totalitarian ideology looks at individual human beings as instruments, as means of realization of a political, even cosmic project" (Todorov 1996, quoted from Mușat 1998: 166). ${ }^{2}$ Moreover, from Todorov's point of view, "the life of an individual in a totalitarian society equals life lived in a submarine" (Mușat 1998: 169).

2 Here and henceforth quotes translated from Romanian by the author of this article. 
$\mathrm{IACOB}$

In a discussion about the interaction of a movement with a certain culture, for instance, the interaction between Romania and postmodernism, I believe a very short description of the socio-political and cultural climate would be in order simply because it can provide a series of answers and explanations to the particular forms of postmodernism in Romania. The importance of the context and of the historical differences between Western Europe and Eastern Europe is a starting point for an interesting axiological-comparative approach of postmodernism, and it also invites to an investigation of the human condition within these two distinct political hemispheres.

To somebody from the Eastern part of Europe, postmodernism comes as an alternative to the calamitous space of totalitarian oppression and as a chance to regain the "uncosmeticised" reality. Discussing specifically Romania, we are dealing with a marginal culture by excellence, an aspect which triggered the slow diffusion of the echo of new artistic tendencies, especially in the period of massive deterioration (in the 1970s and the 1980s) and of the accentuated isolation of Nicolae Ceaușescu's dictatorship. Among many other things, communism has also brought inertia instead of progress, a suspension in nothingness, and also a state of confusion derived from the illusion of synchronization as the totalitarian reality did not coincide with the Western reality. Therefore, Romanian postmodernism aims to rehabilitate "the real reality”. One of Romanian literary critics, Carmen Mușat, captures this reflex of constantly feeding the conscience of truth. She says:

Unlike western postmodern literature - especially American postmodern literature - which reflects a derealised reality mainly through mass-media and Hollywood strategies, Romanian postmodernism attempts to re-establish the essential coordinates of a reality threatened with disappearance under the avalanche of discourses held by party activists. (Mușat 1998: 100)

The essential procedure for a Romanian postmodern writer is the appropriation of reality, a return to reality and a thorough analysis of all its mundane parts which somehow manage to escape ideological influences, the focus being laid more on experiences and authenticity.

Being an alternative form which tries to stoically survive the totalitarian vicissitudes, postmodernism has a subversive side not only because of its structure which is incompatible with the system, but also because of its techniques. The conscience of postmodern writers is not afraid of fragmentation, puzzles, intertwined plans, narrative fireworks as it does not fear the use of humour and irony meant to dismember the false representation of the utopian reality. Many of the features of postmodernism come into conflict with the communist ideology. 
Carmen Mușat points out the multidimensional framework of postmodernism in a world dominated by the practice of singularity - an aspect related to an ontological incongruity between the multiple perspectives that a novel offers and the one single perspective imposed by the state, as well as the problem of the dual nature of the individual, the promotion of the "wooden language" in order to suggest seriousness, the paranoid vigilance and circumspect attitude towards word-play, humour, irony or other strategies (Muşat 1998: 101).

Obviously, within this totalitarian background, the slow dissemination of postmodern guidelines oriented towards pluralism, decentralization and relativity results in an incomplete process of post-modernization in Romania. One of the most famous literary works which depicts the deeply hostile and suspicious attitude of authorities towards any form of wit that dares to question the infallibility of the system is Milan Kundera's novel, The Joke. Humour is indeed a serious matter, as Peter Gay begins one of his essays named The Bite of Wit. In a totalitarian state like Romania, where the state is basically everywhere, almost all forms of humor are political and almost any joke is subversive because it contains an attack towards a chimerical, falsified system, which in fact did not want to be the object of anyone's laughter. Humour is a serious matter because it courageously returns to transparency, thus revealing the cruel truth: that the emperor wears no clothes; that reality has nothing to do with the communist ideals. Postmodernism brings about a literature of disagreement, as Carmen Mușat calls it, that tries to overthrow the fictitious, utopian reality imposed by the single party. By putting the political aspects in parenthesis, postmodern literature will be a literature about reality as it is, not as it was made to appear: "although it defines itself as realist, it has nothing in common with the so-called socialist realism” (Mușat 1998: 101).

Postmodernism appears as a phenomenon based on incongruities as well. It does not part with the past, because it knows that the past cannot be avoided, however it refuses it by reinterpreting it with irony or parody. Postmodernism is a deviation from the convention, as a critique of the tradition of forms, suggesting instead textual innovation, a playful attitude to time and place, a mélange of possible worlds, the destabilization of narrative cohesion by fragmentation, the use of humour, the importance of every individual as a potential carrier of stories.

The prolonged refuge in the library of the ' 80 s generation creates the illusion that reality itself is a huge library and people's destinies are texts that should be read. (Mușat 1998: 104) 
$\mathrm{IACOB}$

All in all, the great merit of postmodernism in Romania is that it brought along the perspectives of pluralism. The paradox of this cultural mutation which incorporates contrary feelings: anxiety and serenity places the individual in a new world situated at the intersection of a "funhouse" and a "slaughterhouse", as Mircea Cărtărescu would put it (Cărtărescu 1999: 408).

\section{Ioan Groșan and Humour in the Postmodern Romanian Prose}

In the context of communism as illusion of totality, there comes to light literary democracy, with a very witty, ironic spirit. The experiments in prose prove the existence of an elitist humor, mature enough to juggle with alternative spaces and to inspect the anatomy of reality and writing. Ioan Groșan would be one example, and he does this in quite a humorous way. In his short story called Insula (The Island, 2005) the author presents a series of crises and postmodern dilemmas by the use of a love story, reinterpreted with humour and parody, under the form of fragments taken from previous literary periods. The crises presented in his work revolve around language, identity, and writing. The conflict engages the scriptural dimension with the ontological dimension, by always taking into account previous forms of writing. The rethinking of this relationship with the past triggers new and contrasting pairs concerning the form, the topics, mechanisms, and style which suddenly turns from preciousness and mannerism to orality, irony, playfulness, and a colloquial tone.

In short, the narrator, who happens to be in love, recounts a dream where he finds himself on a deserted island filled with books, devoid of the capacity to use his own words, therefore being forced to "literarize" his vocabulary in order to speak to his loved one. The "literarization" will be reflected upon the Adamic couple, the experience of love itself being supported by recycling literary fragments. Not only their everyday small chat is "read" or lived as "reading"; love itself becomes an experience mediated by intertextuality, as an incandescent feeling transmitted through quotes. This reminds us of Umberto Eco who said that we can no longer live and talk by claiming authenticity. However, there is a solution with which one can fool the limits of language:

The postmodern attitude seems to me like that of a man who loves a very intelligent and well-learned woman and therefore knows that he cannot say to her: 'I love you desperately' because he knows that she knows (and she knows that he knows) that exactly these words already have been written by, let's say Liala. But there is one solution left 'As Liala would say, I love you desperately!' (Eco 1983, quoted from Cărtărescu 1999: 80.) 
This is basically the incongruity: that there is still a possibility to feel innocent in an age of lost innocence.

By accepting to enter this game of literary references, of communication by the use of fragments, the two characters borrow masks which help them quote their existence, offering the reader one of the most captivating passages of "texistence", in Cărtărescu's terms, where the ontological dimension exercises and perfects its conversion to literature until it reaches the point of complete "literarization":

We spent hours immersed between pages, diligently copying fragments of dialogue, simple sentences, interjections, sayings, greetings etc. After a week, we had learned to talk a few minutes in a row.

You look tired today (Dreiser) - I would say. 'I have a headache' (Cezar Petrescu) - you would answer. 'Let's get out of here!' (Tchekhov). 'No!' (Ionescu). 'Come and eat something' (Sadoveanu). 'I don't want to!' (The Death of Yuan Mei). 'I would take a break to recollect my thoughts.' 'This morning I saw the strangest animal on the peninsula.' (Mihai Tican Rumano). 'What are you talking about?!' (Caragiale). 'I think we better get out of here.' (Faulkner). 'Wouldn't it be better to defend ourselves here?' (Jules Verne). 'How?' (Camus). 'Well, let's take a shovel...' (A. Toma). 'That's not a solution.' (Eusebiu Camilar). 'Auch!' (Joyce). 'What's wrong?' (Ibsen). 'This terrible migraine.' (Huxley). 'Does it hurt badly?' (Ionel Teodoreanu). 'Like hell, if only you knew!...' (Gib Mihăiescu). 'Indeed, my angel, I understand...' (Bolintineanu). 'You don't understand anything. And why are you looking at me like that?' (Agatha Christie). 'I love you' (Ion Grecea). 'Oh, please, spare me...' (Dostoyevsky). 'Don't you want to be together any more?' (Cella Serghi). 'I didn't say that I don't want to, I said that I can't!' (Pascal). 'Then go to hell!' (Brecht). 'You pig!' (Céline). 'Goodbye!' (Breban). ‘Good night!' (Buzzati). (Groșan 2005: 28)

This entire piece of literary reality features an eclectic mélange of writers: minor and major names in literature are convened in this "texistence". However, things take a sudden turn when the two lovers discover the enigmatic question of "who are you?"

By borrowing the identity of the literary characters, the two lovers forgot their own identity. Devoid of their biography, the two "Paper Men", as the title of a book by William Golding would sound like, end up experiencing the consequences of the reversed and incongruent relation between reality and literature, between existence and text. This is what I would like to call an ontic-literary incongruity. By placing fiction ahead of reality, the text before the experience, the two characters end up being ontically devitalized, devoid of experience, of the sense of belonging, in the midst of a conflict between the 
$\mathrm{IACOB}$

human being and logos, noticed by the Italian philosopher Giorgio Agamben since 1977. His theory is that we can no longer talk about experience since it ceases to belong to the individual. He brings Walter Benjamin into discussion, the one who links this crisis to the traumatizing experience of the First World War.

men returned ... grown silent - not richer, but poorer in communicable experience ... What ten years later was poured out in the flood of war books was anything but experience that goes from mouth to mouth. And there was nothing remarkable about that. (Benjamin 1969, quoted from Agamben 1993: 13)

The same could be said about our hardships in Romania in the final years of the totalitarian regime. In his book called Metamorfozele punctului. In jurul experienței revelatoare (Metamorphoses of the Point 2004), Virgil Podoabă points out that:

One of the sure consequences of this matter - that we can naturally add here is, at least for a certain category of writers, the return and use of the literary field as a counterweight to the contemporary insignificance of the everyday life and a refuge from it. (Podoabă 2004: 123)

Groșan's novel appeared in 1985, a time when life had become unbearable in communist Romania. The author's humour is a fertile field for the confluence of two types of humour: the incongruent humor which also mirrors and parallels the attempt of the state to prescribe life, to forcibly insert an algorithm upon life, and the relief-type of humour according to which humorous strategies constitute a defense mechanism triggered by the vicissitudes of a totalitarian regime.

To conclude, the story fails because of the stubborn purpose to "place the cart before the horse", the belief that text can successfully precede existence is eventually proved to be quite the opposite: namely that the starting point of the text is existence and not the other way around, and that the proper direction of development is from experience towards the text. In these relations we find the incongruity between expectations and result, presented in the form of the forced juxtaposition of opposites. This is how Ioan Groșan's incongruent humor works: the "sudden transformation of a strained expectation into nothing" as Kant would put it, where strained means marked by excessive effort or extended beyond proper limits. By means of an incongruent approach, the improper ethics of the state is mirrored and denounced in literature, thus rendering it subversive both for the state and for past literature. The reader expects a love 
story with a normal development and a happy ending, maybe a few elements of humour which are not necessarily related to the experiential organization of the relationship, but they soon become witnesses of a systemic incongruity adventurous and captivating at first, yet unsuccessful in the end. In this particular relation we also see the subversive nature of Groșan's humour, also noticed by Virgil Podoabă who states that

these texts demonstrate the failure of the Borgesian-textualist crisis and the triumph of the narrative talent upon doctrinaire speculation. (Podoabă 2004: 127)

The subversive style has a double meaning: firstly, it is related to the desire to escape the tyranny of the novel and its totalizing pretense (in a higher frame, from the totalizing pretenses of a totalitarian society) by using short prose just as capable to potentiate a writer's talent and secondly, it reflects the absurdity of the reversed logical relations of a system which reveals incongruence as the intrinsic feature of the communist regime in Romania. Just as the reversed relation between existence and text by placing the text in front of existence will generate a crisis of experiential failure, the communist system will also fail because of formal and content related incongruities. Some examples in this sense would be the forced primacy of the public structure of the individual and not of the private structure, the primacy of belief and not of logic, the primacy of the whole and not of the part, the organization of life according to the ideals of the state, forcing it to fit into ideological patterns, and equally forcing history in the name of abstract goals, the desire to give sense to a nonsense, the primacy of representation upon content and substance, the imposition of nationalized economy and the dismissal of free market, of the economy based on supply and demand, and, of course, the primacy of freedom as servitude and not of freedom as a fundamental right.

\author{
Miruna Iacob \\ mirunaiacob10@gmail.com \\ Transilvania University of Brașov \\ Bulevardul Eroilor 29, Braşov 500036 \\ ROMÂNIA / ROMANIA
}


$\mathrm{IACOB}$

\section{Works Cited}

Agamben, G. 1993. Infancy and History: On the Destruction of Experience. London \& New York: Verso.

Benjamin, W. 1969. The Storyteller. - Illuminations. Ed. by H. Arendt. New York: Schocken Books, 83-109.

Bremmer, I. 2010. The End of the Free Market. New York: Portfolio-Penguin.

Cărtărescu, M. 1999. Postmodernismul românesc. București: Humanitas.

Eco, U. 1983. Marginalii si glosse la Numele trandafirului. - Secolul 20, 8-9-10, 103.

Groșan, I. 2005. Caravana cinematografică. Bucharest: Corint.

Gay, P. 1991. The Bite of Wit. - Proceedings of the American Philosophical Society, 135, 3, 327-331.

Kant, I. 1987. Critique of Judgment. Indianapolis/Cambridge: Hackett Publishing Company.

Mușat, C. 1998. Perspective asupra romanului românesc postmodern și alte ficțiuni teoretice. Pitesti: Paralela 45.

Podoabă, V. 2004. Metamorfozele punctului. În jurul experienței revelatoare. Pitești: Paralela 45.

Shultz, T. 1976. A Cognitive-Developmental Analysis of Humor. - T. Chapman, H. Foot, eds., Humor and Laughter: Theory, Research and Applications. New York: Wiley, 12-13.

Todorov, T. 1996. Confruntarea cu extrema. Victime și torționari în secolul XX. Transl. by T. Nica. București: Humanitas. 